\title{
Reviews
}

\section{Seán McCorry}

\section{"Thus, I Give Up the Spear!": Sovereignty and Violence Against Animals}

Dinesh Joseph Wadiwel, The War Against Animals. With a Foreword by Matthew Calarco. Leiden: Brill, 2015. xii+302 pp. $\$ 75.00$.

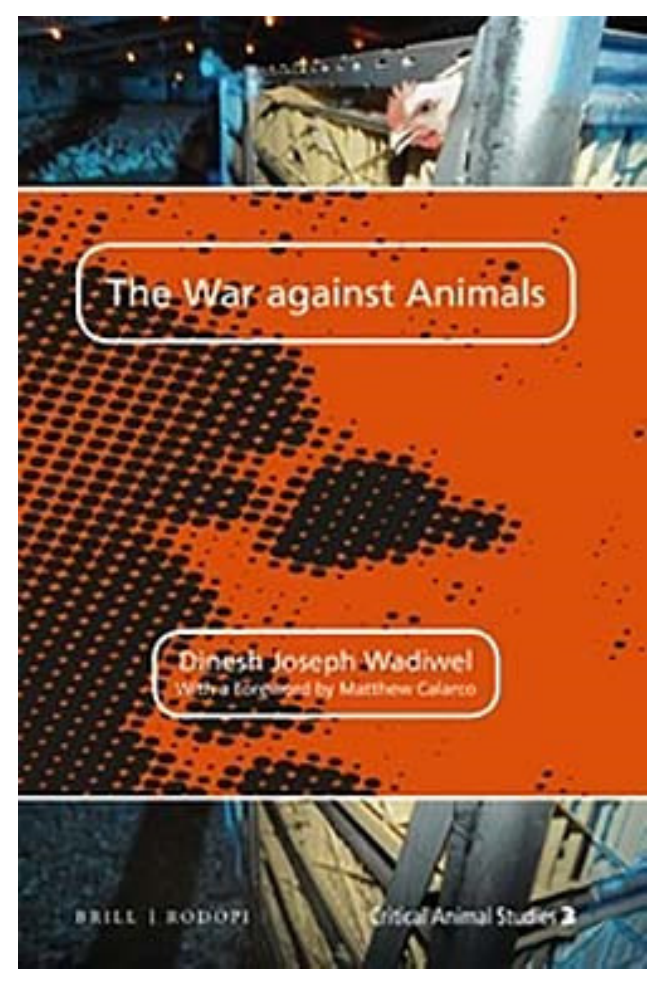

What would it mean to think through the politics of human-animal relations by beginning not with an analysis of mutually enriching relationality, co-shaping, and becoming-with, but rather with an attentiveness to the violence of human sovereignty over nonhumans; a bloody, seemingly endless war carried out beneath a veneer of peaceable civility? How would we have to reorganize our politics, ontologies, and epistemologies to accommodate this primary fact of domination? These are the questions which animate Dinesh Wadiwel's The War Against Animals, a timely and important contribution to a burgeoning literature on the politics - or more precisely, the biopolitics - of human-animal relations. As the title suggests, Wadiwel's book argues that our relations with animals constitute a war of unprecedented violence, albeit one which is radically asymmetrical and largely hidden from view. In Wadiwel's estimation, this state of war is licensed by the unlimited human sovereignty over the 
nonhuman, and this sovereign prerogative impacts on seemingly benign as well as nakedly violent aspects of human-animal relations.

The War Against Animals makes the case for a significantly revised theory of political sovereignty which can account for the peculiar and excessive violence we humans do to our nonhuman others. Engaging with animal-oriented political thinkers such as Gary Francione, Will Kymlicka, and Sue Donaldson, as well as familiar figures from European theory (Foucault, Derrida, and Agamben are all discussed at length), Wadiwel emphatically rejects the sovereign pretensions of humanity, which he identifies not only in the manifest violence of industrialized slaughter, but also in the quotidian (and supposedly peaceable) practices of living with companion animals. Taking issue with Kymlicka and Donaldson's analysis of animal sovereignties, and with the advocates of Great Ape sovereignty, Wadiwel suggests that animal political agency must not be thought on the basis of their similarity to human forms of social organization; that is, on their ability to be incorporated within a humanist conceptual vocabulary of representation, citizenship, population, territory, and security.

These inherited concepts are critiqued for belonging to a pernicious (and bloody) tradition of biopolitical sovereignty, and a tradition, moreover, which is thoroughly implicated in the human domination of nonhuman animals.

If, as Agamben describes, biopolitics is an expression of the distinction between humans and animals - a veritable moving zone of conflict then we might perceive that any model of political membership that prescribes citizenship based upon inside/outside relationships will already be biopolitical, and will already reinscribe the borders between human and animal, even if the terms of that political membership might change. (248)

The first two chapters of The War Against Animals carefully set out this critique of biopolitics, joining a growing literature on nonhuman biopolitics by scholars such as Cary Wolfe, Nicole Shukin, and Matthew Chrulew, among others. Chapter 3 interrogates the logic of "immunity," through which, "quite literally, we kill and make animals suffer to immunise (or securitise) a conceptualisation of the human" (60). Reading Francione together with Karl Marx and John Locke, Chapter 4 analyzes property rights as central to human sovereignty over animals. Chapters 5 and 6 focus on the privatization of sovereignty; that is, "the process by which war is conducted utilising individual humans as agents within a broader conflict" (60). Chapter 6 in 
particular will be of interest to animal studies scholars who research companion animal relationships, as it contains a sustained critique of Donna Haraway's important work on companion species. Wadiwel argues that, in a state of generalized war against animals,

Personal actions work in concert with institutional forms of violence that constrain our companions in particular ways to meet human utility. Epistemic violence allows us to name these relations, almost without a moment of self-reflection, under the guise of "friendship." (219)

Chapters 7 and 8 engage directly with theories of sovereignty, with Chapter 7 engaging with liberal theorists of animal sovereignty (discussed briefly above), and Chapter 8 arguing that sovereignty itself is a "groundless claim" (62) through which humans declare their superiority over (and thus their right to dominate) animals following their victory over them. Wadiwel argues that "force in this case precedes the epistemic claim of superiority, and not the other way around. Human 'superiority' is nothing more that the artifice of our own practices of violent domination over other animals" (62).

Animal welfare advocates find little sympathy here. For Wadiwel, welfare is best theorized as a strategy of power which, more often than not, is thoroughly complicit with (and indeed instrumentally invaluable to) the machinery of killing. Referring to Temple Grandin's famous curved corrals which spare cows destined for slaughter the spectacle of their peers going to their deaths, Wadiwel argues that, in addition to accounting for the psychological "welfare" of the animals, "the curves are also there to subdue resistance and enable the effective and smooth process of slaughter, maximising human utilisation (and profit) value" (12).

Wadiwel's critique of welfarism is central to his analysis of the relationship between sovereignty and the existing paradigm of animal ethics. In his account, sovereignty precedes ethics. We dominate animals because we can, and we retroactively construct myths of our own superiority to justify this domination. Most animal ethics (and certainly all animal welfare theory) treat this domination as an established fact, and seek to negotiate the terms of our ongoing domination:

We offer welfare to those we have dominion over, and wish to continue to dominate for our own benefit, but have the freedom to provide forms of limited consideration that do not temper our dominion right (captured perfectly in that diabolical phrase "unnecessary suffering"). (22)

Humanimalia: a journal of human/animal interface studies

Volume 7, Number 2 (Spring 2016) 
As an alternative to this, Wadiwel proposes that we work to undo human sovereignty, rather than constructing an ethics which is antecedent to the fact of domination: "The challenge, the ethical challenge no less, is to identify and unpick sovereignty in the first instance, rather than attempt to construct an ethics after sovereignty has organised hierarchical divisions" (55).

Certainly, The War Against Animals will raise objections from scholars who are sympathetic to Harawayan readings of human-animal relations. There is little sympathy in Wadiwel's book for the rhetoric of encounter, co-shaping, and relationality which are the hallmarks of the dominant theoretical perspective in animal studies. For Wadiwel, in so far as these potentially enriching encounters with animals leave the presumption of sovereignty intact, they are just another front in an interminable war. His political investments place him closer to work done under the banner of critical animal studies, not least in his suggestion that veganism is a necessary but insufficient condition for the remaking of human-animal relationships beyond the prerogatives of sovereign domination.

The War Against Animals is written in an engaging prose style, and is animated throughout by a refreshingly honest anger at the violence and horror of the human domination of animals. For those of us who are committed to ending - rather than managing - this violence, Wadiwel's book is an important and necessary intervention in animal studies scholarship. 